University of Nebraska - Lincoln

DigitalCommons@University of Nebraska - Lincoln

\title{
Characterization of Testing Locations for Developing Cool-Season Grass Species
}

Joseph G. Robins

USDA-ARS, joseph.robins@usu.edu

Blair L. Waldron

USDA-ARS

Kenneth P. Vogel

University of Nebraska-Lincoln, kvogel1@unl.edu

John D. Berdahl

USDA-ARS

Marshall R. Haferkamp

USDA-ARS

See next page for additional authors

Follow this and additional works at: https://digitalcommons.unl.edu/usdaarsfacpub

Robins, Joseph G.; Waldron, Blair L.; Vogel, Kenneth P.; Berdahl, John D.; Haferkamp, Marshall R.; Jensen, Kevin B.; Jones, Thomas A.; Mitchell, Robert B.; and Kindiger, Byran K., "Characterization of Testing Locations for Developing Cool-Season Grass Species" (2007). Publications from USDA-ARS / UNL Faculty. 1940.

https://digitalcommons.unl.edu/usdaarsfacpub/1940

This Article is brought to you for free and open access by the U.S. Department of Agriculture: Agricultural Research Service, Lincoln, Nebraska at DigitalCommons@University of Nebraska - Lincoln. It has been accepted for inclusion in Publications from USDA-ARS / UNL Faculty by an authorized administrator of DigitalCommons@University of Nebraska - Lincoln. 


\section{Authors}

Joseph G. Robins, Blair L. Waldron, Kenneth P. Vogel, John D. Berdahl, Marshall R. Haferkamp, Kevin B. Jensen, Thomas A. Jones, Robert B. Mitchell, and Byran K. Kindiger 


\title{
Characterization of Testing Locations for Developing Cool-Season Grass Species
}

\author{
Joseph G. Robins, ${ }^{\star}$ Blair L. Waldron, Kenneth P. Vogel, John D. Berdahl, Marshall R. Haferkamp, \\ Kevin B. Jensen, Thomas A. Jones, Robert Mitchell, and Bryan K. Kindiger
}

\begin{abstract}
The identification of best testing locations facilitates the allocation of resources in a breeding program, allowing emphasis to be placed at the sites best suited for identifying superior plant materials for the target environment. The objective of this study was the identification of best locations for the evaluation and testing of cool-season grass species within the Northern Great Plains and Intermountain regions of the USA. This study also sought to subdivide the locations into meaningful environmental groupings based on similar entry performance. The study characterized initial stand frequency and forage production (over a 3-yr period) of crested wheatgrass [Agropyron cristatum (L.) Gaertn.; A. desertorum (Fisch. ex Link) Schultes; $A$. fragile (Roth) Candargy], intermediate wheatgrass [Thinopyrum intermedium (Host) Barkworth \& D.R. Dewey], and smooth bromegrass (Bromus inermis Leyss.) at six locations within these regions. Results suggested the existence of best testing locations and environmental groupings for each of the species. For example, the Ithaca, NE, location was consistently a good location for testing forage production. Although there were some consistencies, generally, the best testing locations and environmental groupings were species and trait specific. Thus, the targeted use of locations appeared to be most useful on an individual species basis, rather than considered across the cool-season grass species.
\end{abstract}

J.G. Robins, B.L. Waldron, K.B. Jensen, and T.A. Jones, Research Geneticists, USDA-ARS Forage and Range Research Lab., Utah State Univ., Logan, UT 84322-6300; K.P. Vogel, Supervisory Research Geneticist, and R. Mitchell, Rangeland Scientist, USDA-ARS Grain, Forage, and Bioenergy Research Unit, Univ. Nebraska, Lincoln, NE 68583-0937; J.D. Berdahl, Research Geneticist (Retired), USDA-ARS Northern Great Plains Research Lab., Mandan, ND 58554; M.R. Haferkamp, Rangeland Scientist (Retired), USDA-ARS Ft. Keogh Livestock and Range Research Lab., Miles City, MT 59301-4016; B.K. Kindiger, Research Geneticist, USDA-ARS Grazinglands Research Lab., El Reno, OK 73036. Mention of a trademark, proprietary product, or vendor does not constitute a guarantee or warranty of the product by the USDA. Received 26 Sept. 2006. ${ }^{\star}$ Corresponding author (joseph.robins@usu.edu).

Abbreviations: PAR, plant adaptation region.

C OOL-SEASON GRASS species are the plant materials of choice for seeding rangelands and pastures in the Northern Great Plains and Intermountain regions of North America. Many of the sites in these areas are disturbed or otherwise damaged and require plant materials with good stand establishment and forage production to rapidly revegetate, return the areas to forage production, and protect the soils from erosion (Wolf et al., 1996). A wide variety of species, representing both native and introduced materials, is available for seeding these areas, and the suitability of a number of these species has been investigated and documented (Asay et al., 2001; Vogel and Jensen, 2001). However, a weakness of many potential grass species is their inability to rapidly establish a dense stand, maintain that stand (persist), and produce forage for many years.

Published in Crop Sci. 47:1004-1012 (2007).

doi: 10.2135/cropsci2006.09.0619

(C) Crop Science Society of America

677 S. Segoe Rd., Madison, WI 53711 USA

All rights reserved. No part of this periodical may be reproduced or transmitted in any form or by any means, electronic or mechanical, including photocopying, recording, or any information storage and retrieval system, without permission in writing from the publisher. Permission for printing and for reprinting the material contained herein has been obtained by the publisher. 
While some species commonly grown in the Northern Great Plains and Intermountain USA are important only for specific areas, other species are commonly grown throughout these regions. Three of the more important species used in these regions are crested wheatgrass [Agropyron cristatum (L.) Gaertn.; A. desertorum (Fisch. ex Link) Schultes; $A$. fragile (Roth) Candargy], intermediate wheatgrass [Thinopyrum intermedium (Host) Barkworth \& D.R. Dewey], and smooth bromegrass (Bromus inermis Leyss.). Breeding efforts aimed at improving these and other cool-season grass species are ongoing at several locations. Because of the importance of these species in these regions, the identification of best testing locations and environmental groupings of locations would be useful. Similar studies in other crop species, such as wheat (Triticum aestivum L., Trethowan et al., 2003), cotton (Gossypium hirsutum L., Blanche and Myers, 2006), and barley (Hordeum vulgare L., Navabi et al., 2006), have provided detailed information on common testing locations that should be incorporated into future crop improvement efforts.

The objective of this study was to determine locations most appropriate for developing and testing crested wheatgrass, intermediate wheatgrass, and smooth bromegrass for use in the Northern Great Plains and Intermountain regions. Specifically, this study aimed to (i) identify locations best suited for evaluating and testing improved cultivars of these species, (ii) identify useful environmental groupings of the locations included in the study based on entry performance, and (iii) determine whether best testing locations and environmental groupings were the same for each of the three species.

\section{MATERIALS AND METHODS Plant Materials}

Three cool-season grass species were included in the study: crested wheatgrass, intermediate wheatgrass, and smooth bromegrass. These grass species represent species well adapted and commonly used throughout the Northern Great Plains and Intermountain regions (Balasko and Nelson, 2003). Additionally, these species were being used in ongoing breeding programs at more than one of the locations represented in this study. Each species was represented by 7 to 14 cultivars/breeding populations and will be referred to as entries (Table 1).

\section{Locations}

The study utilized the following sites: Blue Creek, UT ( $41^{\circ} 56^{\prime} \mathrm{N}$, $112^{\circ} 26^{\prime} \mathrm{W}$ ), with Parley's silt loam (fine-silty, mixed, mesic, Calcic Argixerolls) soil; North Logan, UT ( $\left.41^{\circ} 46^{\prime} \mathrm{N}, 111^{\circ} 47^{\prime} \mathrm{W}\right)$, with Green Canyon gravelly loam (loamy-skeletal, carbonatic, mesic Typic Haploxerolls) soil; Mandan, ND (46 48 N, $100^{\circ} 46^{\prime}$ W), with Parshall fine sandy loam (coarse-loamy, mixed, superactive, frigid Pachic Haplustolls) soil; Ithaca, NE (41 $13^{\circ} \mathrm{N}, 96^{\circ}$ $29^{\prime}$ W), with Sharpsburg silt loam (fine, montmorillonitic, mesic Typic Argiudolls) soil; Miles City, MT (46 $22^{\prime} \mathrm{N}, 105^{\circ} 5^{\prime} \mathrm{W}$ ), with fine-loamy, mixed, frigid Aridic Ustochrepts soil; and Sidney, NE ( $\left.41^{\circ} 23^{\prime} \mathrm{N}, 103^{\circ} 0^{\prime} \mathrm{W}\right)$, with Duroc loam (fine-silty, mixed, superactive, mesic, Pachic Haplustolls) soil. The six experimental locations included in this study represent five plant adaptation regions (PARs; Fig. 1) (Vogel et al., 2005b) and are characterized by differences in mean annual precipitation among other climatic and geographic factors (Fig. 2).

\section{Experimental Design and Analysis}

Planting occurred in fall 1999. Seeding was done with cone seeders at a rate of 131 pure live seed linear $\mathrm{m}^{-1}$ at the Nebraska locations and 98 pure live seed linear $\mathrm{m}^{-1}$ at all other locations. At each location, plot arrangement was a randomized complete block design with four complete blocks, with the exception of the Miles City location, which had only three complete blocks. At Mandan and Miles City, individual plots consisted of four 6-m rows with $0.5-\mathrm{m}$ spacing between rows. At the two Utah locations, individual plots consisted of six $5-\mathrm{m}$ rows with $0.3-\mathrm{m}$ spacing between rows. At

Table 1. List of cultivars/breeding populations and their source.

\begin{tabular}{|c|c|c|c|}
\hline Species $^{\dagger}$ & $\begin{array}{c}\text { Cultivar/ } \\
\text { population }\end{array}$ & ID & Reference/source \\
\hline$\overline{C W G}$ & CD-II & $\mathrm{C} 1$ & Asay et al., 1997 \\
\hline CWG & Douglas & $\mathrm{C} 2$ & Asay et al., 1995a \\
\hline CWG & Fairway & $\mathrm{C} 3$ & Kirk, 1932 \\
\hline CWG & $\mathrm{H} \times \mathrm{B} 28$ & $\mathrm{C} 4$ & Utah Experimental \\
\hline CWG & Hycrest & C5 & Asay et al., 1985 \\
\hline CWG & Hycrest-II & $\mathrm{C} 6$ & Utah Experimental \\
\hline CWG & NE_AC1 & $\mathrm{C} 7$ & Nebraska Experimental \\
\hline CWG & Nordan & $\mathrm{C} 8$ & Rogler, 1954; Hein, 1955 \\
\hline CWG & Nordan-HYLD/HDMD & $\mathrm{Cg}$ & Nebraska Experimental \\
\hline CWG & NU-ARS AC2 & C10 & Vogel et al., 2005c \\
\hline CWG & P-27 & $\mathrm{C} 11$ & Hanson, 1972 \\
\hline CWG & Pubescent Siberian & $\mathrm{C} 12$ & Utah Experimental \\
\hline CWG & Ruff-HYLD/HDMD & $\mathrm{C} 13$ & Nebraska Experimental \\
\hline CWG & Vavilov & $\mathrm{C} 14$ & Asay et al., 1995b \\
\hline IWG & $\mathrm{Al}$ & 11 & Utah Experimental \\
\hline IWG & Amur-RMFS & 12 & Nebraska Experimental \\
\hline IWG & Beefmaker & 13 & Vogel et al., $2005 a$ \\
\hline IWG & Greenar & 14 & Hein, 1958 \\
\hline IWG & Luna & 15 & Niner, 1967 \\
\hline IWG & Mandan-I1821 & 16 & North Dakota Experimental \\
\hline IWG & Mandan-I1871 & 17 & North Dakota Experimental \\
\hline IWG & Mandan-I1891 & 18 & North Dakota Experimental \\
\hline IWG & Manska & 19 & Berdahl et al., 1993 \\
\hline IWG & NE_50-RMFS & 110 & Nebraska Experimental \\
\hline IWG & NE_TI3 & 111 & Nebraska Experimental \\
\hline IWG & Oahe & 112 & Ross, 1963 \\
\hline IWG & Reliant & 113 & Berdahl et al., 1992 \\
\hline IWG & Rush & 114 & St. John, 1996 \\
\hline SBG & Century & S1 & Nebraska Experimental \\
\hline SBG & Lincoln & S2 & Hanson, 1972 \\
\hline SBG & Lincoln-HDMD & S3 & Nebraska Experimental \\
\hline SBG & Manchar & S4 & Morrison and Wolfe, 1957 \\
\hline SBG & NE_BI_1 & S5 & Nebraska Experimental \\
\hline SBG & NE_BI_2 & S6 & Nebraska Experimental \\
\hline SBG & NE_BI_4 & S7 & Nebraska Experimental \\
\hline
\end{tabular}

${ }^{+} \mathrm{CWG}$, crested wheatgrass; IWG, intermediate wheatgrass; SBG, smooth bromegrass. 


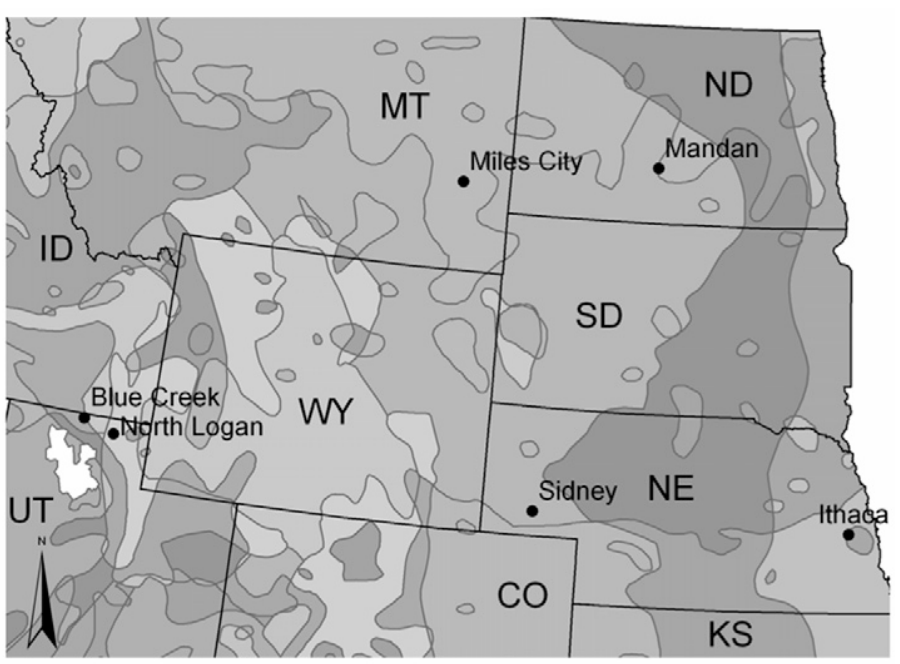

\section{Legend}

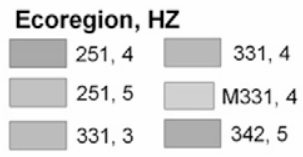

Figure 1. Plant adaptation regions of the Northern Great Plains and Intermountain regions of the USA, with identifiers for each location included in the study. PAR 251,4: Prairie Parkland (Temperate) Ecoregion, Hardiness Zone 4; PAR 251,5: Prairie Parkland (Temperate) Ecoregion, Hardiness Zone 5; PAR 331,3: Great Plains-Palouse Dry Steppe Ecoregion, Hardiness Zone 3; PAR 331,4: Great PlainsPalouse Dry Steppe Ecoregion, Hardiness Zone 4; PAR M331,4: Southern Rocky Mountain Steppe, Open Woodland, Coniferous Forest, Alpine Meadow Ecoregion, Hardiness Zone 4; PAR 342,5: Intermountain Semidesert Ecoregion, Hardiness Zone 5.

the Nebraska locations, individual plots consisted of seven 4.5-m rows spaced $0.15 \mathrm{~m}$ apart. All plantings were fall dormant plantings with emergence the following spring.

\section{Data Collection and Analysis}

Data include initial stand frequency from 2001 and forage production from the 2001, 2002, and 2003 growing seasons at all sites. Initial stand frequency was estimated using the methods described by Vogel and Masters (2001). Briefly, this estimation consisted of the number of squares $\left(15 \mathrm{~cm}^{2}\right.$ in a grid) out of 50 containing rooted, live plant material. The ratio of the number of squares within the grid containing plant material to the total number of squares within the grid was calculated and converted to a percentage.

Forage production was estimated by machine harvesting to a stubble height of $\sim 15 \mathrm{~cm}$ and measuring plot forage wet weights. After forced-air drying at $60^{\circ} \mathrm{C}$, dry weights were determined. These weights were then converted to $\mathrm{kg} \mathrm{ha}^{-1}$ for the resulting forage production values. At Mandan, Miles City, and both Utah locations, $0.5 \mathrm{~m}$ was trimmed from the ends of each plot before harvest to minimize border effects, and then only the two middle rows were harvested. At the Nebraska locations, plots were trimmed to uniform 3-m lengths before harvest, and a 0.91-m swath was harvested from the center of each plot. Forage was harvested once per year at all locations, except the Nebraska locations, where it was harvested twice per year. All values were converted to yearly forage totals in $\mathrm{kg} \mathrm{ha}^{-1}$.
Data were analyzed using the MIXED procedure of SAS (Littell et al., 1996; SAS Institute, 2006). The statistical model considered the main effect due to entries as fixed and all remaining main effects (locations, years, and blocks) and interactions as random. Further examination of the entries and the entry $\times$ location interaction occurred with the GGEbiplot software (Yan, 2001; Yan and Kang, 2003; Yan and Tinker, 2005). The GGEbiplot model employed was the tester (location)-centered model based on singular value decomposition of the untransformed data standardized by the within-tester (location) standard error.

\section{RESULTS AND DISCUSSION Environmental Conditions}

Locations included in this study represent a variety of climatic conditions of the Northern Great Plains (Ithaca and Sidney, NE; Mandan, ND; and Miles City, MT) and Intermountain (Blue Creek and North Logan, UT) regions of the USA. With the exception of Ithaca, locations included in this study represent semiarid regions of the USA. Locations are also characteristic of various PARs (ecoregions described by Bailey, 1995; Vogel et al., 2005b) (Fig. 1). Ithaca lies on the border between hardiness zones 4 and 5 of the Prairie Parkland (Temperate) Ecoregion. Mandan, Miles City, and Sidney all lie within the Great Plains-Palouse Dry Steppe Ecoregion but are split between hardiness zones 3 and 4 . North Logan is in hardiness zone 4 of the Southern Rocky Mountain Steppe, Open Woodland, Coniferous Forest, Alpine Meadow Ecoregion. Blue Creek is in hardiness zone 5 of the Intermountain Semidesert Ecoregion. These PARs are characterized by differences in climate and predominant vegetation, among other things.

A key difference between the locations was precipitation. Thirty-year mean precipitation levels range from $\sim 300 \mathrm{~mm} \mathrm{yr}^{-1}$ at Miles City to $\sim 700 \mathrm{~mm} \mathrm{yr}^{-1}$ at Ithaca (Fig. 2). Based on 30-yr site averages and with some yearly deviations, the general trend throughout the study was normal to near-normal precipitation levels for the four eastern locations (Fig. 2). The Intermountain USA, including

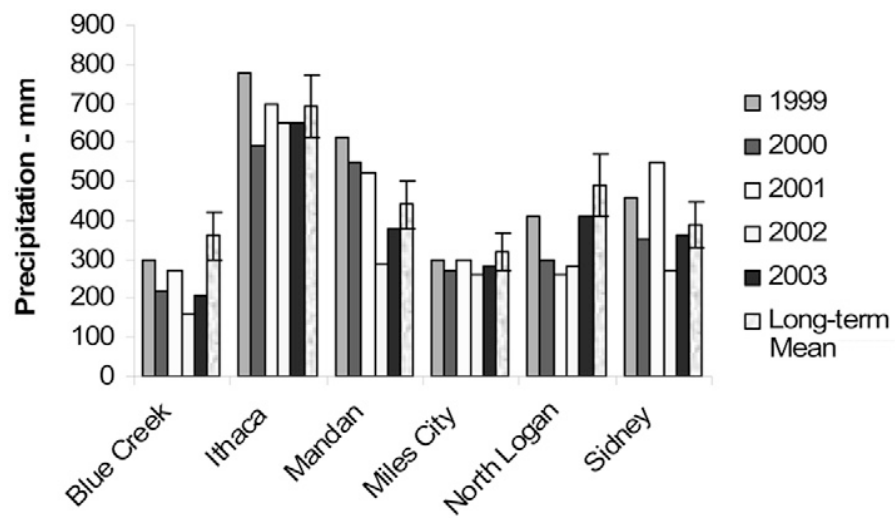

Figure 2. Display of actual precipitation levels $(\mathrm{mm})$ for each year of the study (1999-2003) and the 30-yr mean precipitation level for each location with LSD bars for comparisons among years at the same location. 
the Blue Creek and North Logan locations, experienced an extended drought during the period of this study. Blue Creek had below-normal precipitation each year except 1999, and North Logan had below-normal precipitation from 2000 to 2002.

\section{Mixed Model Analysis}

Population means for initial stand frequency and forage production differed among the crested wheatgrass and smooth bromegrass populations, but there were no differences among intermediate wheatgrass population means for either trait (Table 2). Although no differences occurred among intermediate wheatgrass entries analyzed on total yearly production across all locations, within the Nebraska locations there were differences among the entries when analyzed on an individual harvest basis (data not shown). Variation due to location was not significant for either trait for any of the species, but entry $\times$ location interaction was significant for each trait and for each species (Table 2). Because entry $\times$ location interaction was significant for each trait and species, analysis of the resulting data with biplot techniques was an appropriate method of interpreting the data.

Perennial grasses must survive over vastly different year-to-year conditions that are very unpredictable. Clearly, the effect of different years has a substantial effect on entries at a given location. However, the identification of best yearly conditions has little value in experimental or production settings because the yearly effects cannot be chosen before planting. We felt the characterization of the locations across different years would be of most usefulness. Thus, because of the yearly unpredictability (and due to the focus of this study on locations), the effect of years and the interaction between entries and years, although included in the mixed model analysis, were not addressed. The sum of the first and second principal components (PC1 and PC2) explained between 65 and $87 \%$ of the standard error standardized, locationcentered model variation (depending on the trait and species) (Fig. 3). These levels of variation adequately, although not perfectly, represent the standardized data and allow conclusions to be drawn on the underlying entry $\times$ location interaction (Yan and Kang, 2003; Yan and Tinker, 2006).

Only initial stand frequency (2001) was taken from each location. Initial stand frequency represents both seed quality and entry performance due to genetics. Subsequent year stand frequency is more reflective of persistence but was not collected from all locations included in the study. For those locations from which subsequent year stand frequency was collected, the results, generally, reflected the initial year stand frequency results. Due to the limited number of locations from which data was taken, sub- sequent year stand frequency data was not subjected to biplot analysis.

\section{Environmental Grouping and Testing Ability of Locations}

On a biplot display, the cosine of the angle between the vectors (i.e., lines that connect the locations to the biplot origin) of two locations approximates the correlation between the two locations in ranking the entries: the smaller the resulting angle, the more highly correlated the locations (Yan and Kang, 2003; Yan and Tinker, 2006) (Fig. 3). Correlation coefficients between each set of locations were also calculated (Table 3). Based on the biplot analysis and correlation values, environmental groupings were identified, which represented groupings of locations within the target region where tested plant materials behaved similarly (Gauch and Zobel, 1997). This concept of identifying similar testing locations has been used for a number of species (Yan et al., 2000; Trethowan et al., 2003; Navabi et al., 2006).

The concept of the ideal testing location is characterized by the combined ability of locations to discriminate among entries included in the study and to be representative of other locations in the overall environment of interest (Yan and Kang, 2003; Yan and Tinker, 2006). This concept has also been used for other crops (Blanche and Myers, 2006; Dehghani et al., 2006). Discriminating ability refers to a location's ability to maximize the variance among entries in a study (Blanche and Myers, 2006). Representativeness suggests that a location is representative of the conditions of other locations included in the study (Yan and Tinker, 2006). An ideal testing location combines both of these traits for the development of generally adapted plant materials (Yan and Tinker, 2006). These values are best viewed with the "discriminating power vs. representativeness of testers" biplot display of GGEbiplot (Yan and Kang, 2003; Yan and Tinker, 2006). The discriminating ability of locations is most easily visualized by counting the number of rings separating the location from the origin of the biplot display (Yan and Tinker,

Table 2. Results of mixed model analysis. The entry column contains $p$ values from the analysis of difference among entry means (ranges of entry means are included in parentheses). The $V(L)$ and $V(E x L)$ columns contain the variance component estimates ( \pm standard errors of estimates) of location and entry $\times$ location interaction.

\begin{tabular}{lccc}
\hline & Entry & $\mathrm{V}(\mathrm{L})$ & $\mathrm{V}(\mathrm{ExL})$ \\
\hline Initial stand frequency $^{\dagger}$ & $\%$ & & \\
$\mathrm{CWG}$ & $0.005(66-83)$ & $105 \pm 77$ & $40 \pm 12$ \\
IWG & $0.15(81-93)$ & $132 \pm 174$ & $11 \pm 5$ \\
SBG & $0.01(60-76)$ & $222 \pm 188$ & $56 \pm 21$ \\
Forage production & $\mathrm{kg} \mathrm{ha}^{-1}$ & & \\
CWG & $<0.0001(1600-3500)$ & $4.6 \times 10^{6} \pm 3.2 \times 10^{6}$ & $1.8 \times 10^{5} \pm 5.3 \times 10^{4}$ \\
IWG & $0.36(3800-4600)$ & $9.3 \times 10^{6} \pm 6.5 \times 10^{6}$ & $1.1 \times 10^{5} \pm 3.7 \times 10^{4}$ \\
SBG & $0.002(2100-3100)$ & $6.3 \times 10^{6} \pm 4.2 \times 10^{6}$ & $1.0 \times 10^{5} \pm 4.3 \times 10^{4}$ \\
\hline
\end{tabular}

${ }^{\dagger} \mathrm{CWG}$, crested wheatgrass; IWG, intermediate wheatgrass; SBG, smooth bromegrass. 
2006) (Fig. 3). The more rings separating the location from the origin of the graph, the more discriminating the location is (Yan and Tinker, 2006). The representativeness of locations is visualized by the angle formed between the location vectors and the dark line running across the display (average environment axis) and passing through the origin. The smaller the resulting angle, the more representative the location of other sites in the area of interest (Yan and Tinker, 2006) (Fig. 3).

\section{Crested Wheatgrass}

For crested wheatgrass stand frequency and forage production, there was good separation of locations into environmental groups. Group 1 included Ithaca, Mandan, and Miles City; and Group 2 included Blue Creek, North Logan, and Sidney (Fig. 3A, B). There was also high correlation among most of the locations for forage production (Table 3; Fig. 3B), although this may be due to the inclusion of universally poor performing entries that if removed might loosen the correlations (W. Yan, personal communication, 2006). Sidney was an intermediate location between the two groups, but its inclusion with Blue Creek and North Logan was most appropriate because of consistency of entry performance. Group 1 consisted mostly of the more eastern and northern sites with little respect to precipitation.

Table 3. Between-location correlation coefficients (stand frequency correlations above diagonal; forage yield correlations below diagonal) with significance at the $5 \%$ level, from Miles City, MT; Ithaca and Sidney, NE; Mandan, ND; and Blue Creek and North Logan, UT.

\begin{tabular}{|c|c|c|c|c|c|c|}
\hline \multicolumn{7}{|c|}{ Crested wheatgrass } \\
\hline & Blue Creek & Ithaca & Miles City & Mandan & North Logan & Sidney \\
\hline Blue Creek & - & NS & NS & NS & 0.65 & 0.64 \\
\hline Ithaca & 0.64 & - & NS & NS & NS & NS \\
\hline Miles City & 0.58 & 0.82 & - & 0.72 & NS & NS \\
\hline Mandan & 0.58 & 0.91 & 0.85 & - & NS & NS \\
\hline North Logan & 0.64 & 0.66 & NS & NS & - & NS \\
\hline Sidney & 0.75 & 0.70 & 0.70 & 0.69 & NS & - \\
\hline \multicolumn{7}{|c|}{ Intermediate wheatgrass } \\
\hline & Blue Creek & Ithaca & Miles City & Mandan & North Logan & Sidney \\
\hline Blue Creek & - & NS & NS & NS & 0.57 & NS \\
\hline Ithaca & NS & - & NS & NS & NS & NS \\
\hline Miles City & NS & NS & - & 0.63 & NS & NS \\
\hline Mandan & NS & NS & NS & - & NS & NS \\
\hline North Logan & 0.64 & NS & NS & -0.56 & - & NS \\
\hline Sidney & NS & NS & NS & NS & NS & - \\
\hline \multicolumn{7}{|c|}{ Smooth bromegrass } \\
\hline & Blue Creek & Ithaca & Miles City & Mandan & North Logan & Sidney \\
\hline Blue Creek & - & NS & NS & NS & NS & NS \\
\hline Ithaca & 0.65 & - & 0.83 & 0.75 & NS & 0.77 \\
\hline Miles City & 0.70 & 0.79 & - & NS & NS & NS \\
\hline Mandan & NS & NS & NS & - & NS & NS \\
\hline North Logan & NS & 0.79 & NS & 0.80 & - & NS \\
\hline Sidney & NS & NS & NS & NS & NS & - \\
\hline
\end{tabular}

Ithaca had the highest precipitation level (based on 30 yr means) of all locations (Fig. 2), but Mandan had only intermediate precipitation, and Miles City had the lowest precipitation of all locations. Although Mandan lies on the border between PARs 331.3 and 331.4 (Fig. 1) (Vogel et al., 2005b), it shares Ecoregion 331, and likely the PAR 331.3, with Miles City. None of the sites in Group 2 share PARs (Fig. 1) (Vogel et al., 2005b) but are the more western and southern locations. Additionally, North Logan and Sidney had similar precipitation levels (Fig. 2), and Blue Creek and North Logan represented the Intermountain region. For the crested wheatgrass traits, separation of locations into environmental groupings appeared to be based on geography rather than other traits, although the role of precipitation cannot be ruled out.

For crested wheatgrass stand frequency, Mandan was the most discriminating location (Fig. 3A). Blue Creek, Miles City, North Logan, and Sidney had roughly equivalent, yet intermediate, discriminating ability, and Ithaca was the least discriminating location (Fig. 3A). The most representative locations for crested wheatgrass stand frequency were Blue Creek and Miles City (Fig. 3A), although their representativeness was not high. The remaining locations were not representative. Due to the lack of representativeness of the locations, it was difficult to identify a best testing location for Group 1. However, the excellent discriminating ability of Mandan suggested it as a good choice. Additional work on stand frequency at each location would add clarification to these results. Among the Group 2 locations, Blue Creek and North Logan had roughly equivalent discriminating ability, but Blue Creek was more representative.

For crested wheatgrass forage production, the most discriminating locations were Ithaca followed by Blue Creek, Mandan, and Miles City (Fig. 3B). While North Logan and Sidney were both representative, their representativeness was similar to that of Ithaca, Mandan, and Miles City. Blue Creek was less representative. Overall, Ithaca was apparently the best location for testing crested wheatgrass forage production. Ithaca would also be the best location for testing crested wheatgrass forage production in environmental Group 1. The best location for testing crested wheatgrass forage production in Group 2 was unclear due to the lack of a location with both high discriminating ability and good representativeness, but Blue Creek might be the most promising because of its discriminating ability.

The identification of the best testing locations for crested wheatgrass was tenuous. However, due to the consistent environmental groupings of locations for the crested wheatgrass traits, efforts could be focused on developing crested wheatgrass varieties that are environmental group specific.

\section{Intermediate Wheatgrass}

There were three environmental groupings for intermediate wheatgrass stand frequency. Group 1 included Ithaca 

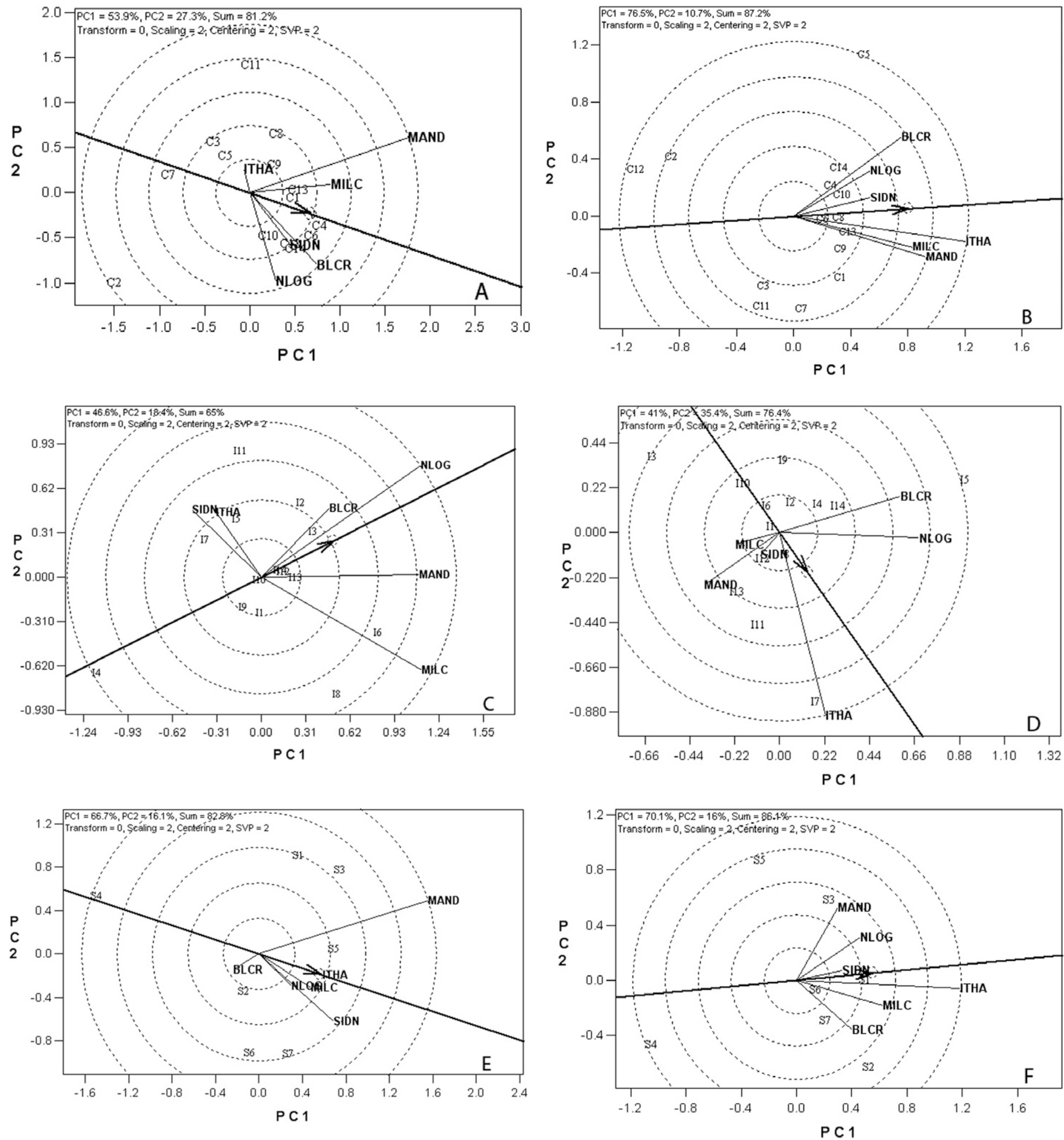

Figure 3. Biplot display of the discriminating power versus representativeness of each location on a species and trait combination basis based on the GGE model (tester-centered based on standard error standardized data) of GGEBiplot (A) crested wheatgrass stand frequency, (B) crested wheatgrass forage production, (C) intermediate wheatgrass stand frequency, (D) intermediate wheatgrass forage production, (E) smooth bromegrass stand frequency, and $(F)$ smooth bromegrass forage production.

and Sidney, Group 2 Mandan and Miles City, and Group 3 Blue Creek and North Logan (Fig. 3C). The groupings shared obvious traits. Group 1 comprised the two Nebraska locations, which were the most central and among the higher-rainfall areas. Group 2 consisted of the Northern areas that also shared a PAR (Fig. 1) (Vogel et al., 2005b). Group 3 consisted of the two Intermountain locations. The groupings for intermediate wheatgrass forage production were almost identical with the exception of the Sidney location, which grouped more closely to the Mandan and Miles 
City locations than to the Ithaca location. Sidney shared an ecoregion with the two northern sites (Fig. 1).

For intermediate wheatgrass stand frequency, North Logan, Mandan, and Miles City were the most discriminating locations (Fig. 3C). The most representative locations were Blue Creek and North Logan. North Logan appeared to be a good location for testing intermediate wheatgrass stand frequency due to its excellent discriminating ability and representativeness. Within the identified environmental groupings, the best testing locations were North Logan and Mandan, due to better representativeness than Miles City, and Sidney. Intermediate wheatgrass forage production was best discriminated at Ithaca, followed by Blue Creek and North Logan (Fig. 3D). Ithaca was the only location exhibiting representativeness for intermediate wheatgrass forage production, making it the best location for testing this trait. In the other two intermediate wheatgrass forage production environmental groupings, Mandan was the best location for intermediate wheatgrass forage production in Group 2, and there was no substantial difference between Blue Creek and North Logan in Group 1.

The identification of best testing locations within environmental groupings for intermediate wheatgrass traits was clearer and more consistent than for crested wheatgrass. Environmental groupings, with the exception of Sidney grouping with the northern locations rather than Ithaca for forage production, were consistent for both traits. Additionally, North Logan was an excellent location for testing both traits in the Intermountain region, and Mandan appeared to be the best location for testing both traits among the northern locations. Ithaca would also be a testing location for both traits, but more due to the fact that it did not group well with the other locations with the exception of Sidney for stand frequency. Thus, targeting intermediate wheatgrass improvement to environmental groupings would be a good tactic and should result in improvements for both traits simultaneously.

\section{Smooth Bromegrass}

Three environmental groupings were identified for smooth bromegrass stand frequency. Group 1 included Blue Creek; Group 2 Ithaca, Miles City, North Logan, and Sidney; and Group 3 Mandan (Fig. 3E). Other than containing both Nebraska locations, there did not appear to be any discernible connection between the sites in Group 2. Ithaca, North Logan, and Sidney were also three of the higherrainfall locations. It appeared that Blue Creek and Mandan form vastly different regions than do the other locations. Two environmental groupings were identified for smooth bromegrass forage production. Group 1 consisted of Mandan, North Logan, and Sidney; and Group 2 Blue Creek, Ithaca, and Miles City (Fig. 3F). Sidney was again an intermediate location, but appeared to fit better with Mandan and North Logan than the other locations. The connection between Group 1 locations was likely due to the already mentioned shared PAR between Mandan and Sidney (Fig. 1) (Vogel et al., 2005b). Additionally the three Group 1 locations were all intermediate in their precipitation levels (Fig. 2) and are sites typically classified as adapted for smooth bromegrass production. Group 2 is less clear because of the differences in precipitation levels and geographic location between Ithaca and the other two sites.

Mandan, followed by Sidney, was the most discriminating location for smooth bromegrass stand frequency (Fig. 3E). Ithaca, Miles City, North Logan, and Sidney were the most representative smooth bromegrass stand frequency locations (Fig. 3E). For smooth bromegrass forage production, Ithaca was the most discriminating location, with little difference among the remaining locations. Ithaca was also very representative (Fig. 3F), making it the best location for testing smooth bromegrass forage production.

Smooth bromegrass improvement did not appear to lend itself to targeted regions, particularly when attempting improvement of both traits simultaneously. Due to the ambiguity associated with the grouping of locations for stand frequency, none of the locations stood out as being best. For forage production, Ithaca was the best location. However, its connection to Blue Creek and Miles City in a grouping might be unrealistic due to vastly differing environmental conditions. There did seem to be good evidence for grouping Mandan and North Logan and then Blue Creek and Miles City for forage production. However, within these two groupings differences between the locations were minor, making recommendations of best testing locations difficult.

\section{Across Traits and Species}

Across both traits (stand frequency and forage production), there was some consistency in the clustering of locations into groupings. With the exception of the smooth bromegrass traits, Blue Creek consistently grouped with North Logan, representing the Intermountain locations, and Mandan consistently grouped with Miles City, representing the northern locations (Fig. 3). However across each of the species, with the above-mentioned exceptions, groupings were not consistent. The overall lack of common groupings and best testing locations across species suggested the need to approach each species individually, at different locations, or with trade-offs between discriminating ability and representativeness. From a practical standpoint the trade-offs approach is most feasible. Thus, a location like Blue Creek might be a good choice for testing crested wheatgrass due to its good discriminating ability and reasonable representativeness for both traits (Fig. 3A, B).

One of the more interesting and consistent findings was the value of Ithaca as a testing location. Ithaca was likely the worst location for testing stand frequency. It was 
one of the least discriminating and, generally, least representative locations for each species. However, for forage production, Ithaca was the most discriminating location and one of the most representative locations for each of the species. This result was most likely due to Ithaca's place as the location with the highest precipitation. The high precipitation likely made evaluation of stand frequency difficult because there was sufficient soil moisture and precipitation to ensure good stands of each species. However, the same precipitation levels made Ithaca a good location for testing forage production because precipitation was not limiting and the species were able to maximize their forage potential. Other consistencies were not as strong as those of Ithaca, and in general, best testing locations were both species and trait dependent.

\section{CONCLUSIONS}

As with other species (Yan et al., 2000; Trethowan et al., 2003; Navabi et al., 2006), environmental groupings and best testing locations (Blanche and Myers, 2006; Dehghani et al., 2006) were identified for each trait and species combination included in this study. However, for the most part, environmental grouping designations and best testing locations were species and often trait dependent. Thus, selection of best locations for testing and development of grass species in the Northern Great Plains and Intermountain regions of the USA should be considered on a species basis.

\section{References}

Asay, K.H., N.J. Chatterton, K.B. Jensen, R.R.-C. Wang, D.A. Johnson, W.H. Horton, and S.A. Young. 1997. Registration of 'CD-II' crested wheatgrass. Crop Sci. 37:1023.

Asay, K.H., D.R. Dewey, F.B. Gomm, D.A. Johnson, and J.R. Carlson. 1985. Registration of 'Hycrest' crested wheatgrass. Crop Sci. 25:368-369.

Asay, K.H., W.H. Horton, K.B. Jensen, and A.J. Palazzo. 2001. Merits of native and introduced Triticeae grasses on semiarid rangelands. Can. J. Plant Sci. 81:45-52.

Asay, K.H., D.A. Johnson, K.B. Jensen, N.J. Chatterton, W.H. Horton, W.T. Hansen, and S.A. Young. 1995a. Registration of 'Douglas' crested wheatgrass. Crop Sci. 35:1510-1511.

Asay, K.H., D.A. Johnson, K.B. Jensen, N.J. Chatterton, W.T. Hansen, W.H. Horton, and S.A. Young. 1995b. Registration of 'Vavilov' Siberian crested wheatgrass. Crop Sci. 35:1510.

Bailey, R.G. 1995. Description of ecoregions of the United States. Inventory and Monitoring Institute, USDA Forest Service. Available at http://www.fs.fed.us/land/ecosysmgmt/ecoreg1_ home.html (verified 11 Mar. 2007). USDA Forest Service, Fort Collins, CO.

Balasko, J.A., and C.J. Nelson. 2003. Grasses for northern areas. In R.F. Barnes, C.J. Nelson, M. Collins, and K.J. Moore (ed.) Forages. Vol. 1. An introduction to grassland agriculture. 6th ed. Iowa State Univ. Press, Ames.

Berdahl, J.D., R.E. Barker, J.F. Karn, J.M. Krupinsky, R.J. Haas, D.A. Tober, and I.M. Ray. 1992. Registration of 'Reliant' intermediate wheatgrass. Crop Sci. 32:1072.
Berdahl, J.D., R.E. Barker, J.F. Karn, J.M. Krupinsky, I.M. Ray, K.P. Vogel, K.J. Moore, T.J. Klopfenstein, B.E. Anderson, R.J. Haas, and D.A. Tober. 1993. Registration of 'Manska' pubescent intermediate wheatgrass. Crop Sci. 33:881.

Blanche, S.B., and G.O. Myers. 2006. Identifying discriminating locations for cultivar selection in Louisiana. Crop Sci. 49:946-949.

Dehghani, H., A. Ebadi, and A. Yousefi. 2006. Biplot analysis of genotype by environment interaction for barley yield in Iran. Agron. J. 98:388-393.

Gauch, H.G., Jr., and R.W. Zobel. 1997. Identifying mega-environments and targeting genotypes. Crop Sci. 37:311-326.

Hanson, A.A. 1972. Grass varieties in the United States. USDA Agric. Handbook 170. U.S. Govt. Printing Office, Washington, DC.

Hein, M.A. 1955. Registration of varieties and strains of wheatgrass (Agropyron spp.), II: Nordan crested wheatgrass (Reg. no. 2). Agron. J. 47:546.

Hein, M.A. 1958. Registration of varieties and strains of grasses, wheatgrass (Agropyron spp.), III: Greenar intermediate wheatgrass (Reg. no. 3). Agron. J. 59:685-686.

Kirk, L.E. 1932. Crested wheatgrass. Univ. of Saskatchewan Ext. Bull. 54. College of Agriculture, Univ. of Saskatchewan, Saskatoon.

Littell, R.C., G.A. Milliken, W.W. Stroup, and R.D. Wolfinger. 1996. SAS system for mixed models. SAS Institute, Inc., Cary, NC.

Morrison, K.J., and H.H. Wolfe. 1957. Manchar smooth bromegrass. Extension Circular 271, Extension Service, Institute of Agricultural Sciences. State College of Washington, Pullman.

Navabi, A., R.-C. Yang, J. Helm, and D.M. Spaner. 2006. Can spring wheat-growing mega-environments in the Northern Great Plains be dissected for representative locations or nicheadapted genotypes? Crop Sci. 46:1107-1116.

Niner, G.C. 1967. Registration of 'Luna' pubescent wheatgrass. Crop Sci. 7:683.

Rogler, G.A. 1954. Nordan crested wheatgrass. Bimonthly Bul. 16:150-152. North Dakota Agric. Coll. Exp. Station Reprint 375. North Dakota State Univ., Fargo.

Ross, J.G. 1963. Registration of 'Oahe' intermediate wheatgrass (Reg. no. 5). Crop Sci. 3:373.

SAS Institute. 2006. SAS system for Windows, version. 9.1. SAS Inst., Cary, NC.

St. John, L. 1996. Notice of release: Rush intermediate wheatgrass (Thinopyrum intermedium). USDA-NRCS Aberdeen Plant Materials Center, Aberdeen, ID.

Trethowan, R.M., M. van Ginkel, K. Ammar, J. Crossa, T.S. Payne, B. Cukadar, S. Rajaram, and E. Hernandez. 2003. Associations among twenty years of international bread wheat yield evaluation environments. Crop Sci. 43:1698-1711.

Vogel, K.P., and K.B. Jensen. 2001. Adaptation of perennial triticeae to the eastern Central Great Plains. J. Range Manage. 54:674-679.

Vogel, K.P., and R.A. Masters. 2001. Frequency grid: A simple tool for measuring grassland establishment. J. Range Manage. 54:653-655.

Vogel, K.P., P.E. Reece, D.D. Baltsensperger, G. Schuman, and R.A. Nicholson. 2005a. Registration of 'Beefmaker' intermediate wheatgrass. Crop Sci. 45:414-415.

Vogel, K.P., M.R. Schmer, and R.B. Mitchell. 2005b. Plant adaptation regions: Ecological and climatic classification of plant materials. Rangeland Ecol. Manage. 58:315-319.

Vogel, K.P., D. Tober, P.E. Reece, D.D. Baltsensperger, G. Schuman, and R.A. Nicholson. 2005c. Registration of 'NUARS AC2' crested wheatgrass. Crop Sci. 45:416-417. 
Wolf, D.D., J.A. Balasko, and R.E. Ries. 1996. Stand establishment. In L.E. Moser, D.R. Buxton, and M.D. Casler (ed.) Cool-season forage grasses. Agron. Monogr. 34. ASA, CSSA, and SSSA, Madison, WI.

Yan, W. 2001. GGEbiplot: A Windows application for graphical analysis of multienvironment trial data and other types of two-way data. Agron. J. 93:1111-1118.

Yan, W., L.A. Hunt, Q. Sheng, and Z. Szlavnics. 2000. Cultivar evaluation and mega- environment investigation based on the GGE biplot. Crop Sci. 40:597-605.
Yan, W., and M.S. Kang. 2003. GGE biplot analysis: A graphical tool for breeders, geneticists, and agronomists. CRC Press, Boca Raton, FL.

Yan, W., and N.A. Tinker. 2005. An integrated biplot analysis for displaying, interpreting, and exploring genotype $\times$ environment interaction. Crop Sci. 45:1004-1016.

Yan, W., and N.A. Tinker. 2006. Biplot analysis of multi-environment trial data: Principles and applications. Can. J. Plant Sci. 86:623-645. 